\title{
How to P(1)ay with Words? The Use of Puns in Online Bank Advertisements in English and Serbian in Light of Relevance Theory
}

\begin{abstract}
Based on a corpus comprising online advertisements of banks operating in the UK and Serbia, this paper aims at describing the most frequent ways of creating puns and classifying them based on their predominant structure. The function of puns in advertising is explained from the perspective of Sperber and Wilson's relevance theory (1995) and the behavioural AIDA model. This paper also tries to reveal whether the formal and semantic aspects of lexical units are exploited in British and Serbian bank offers, and whether there are any language- and culturespecific features in terms of punning.
\end{abstract}

Keywords: puns; bank advertisements; relevance theory; English; Serbian

\section{Kako se igrati/plačati z besedami? Raba besednih iger $\mathrm{v}$ spletnih bančnih oglasih $\mathrm{v}$ angleščini in srbščini v luči teorije relevantnosti}

\section{POVZETEK}

Na podlagi analize korpusa spletnih bančnih oglasov v Britaniji in Srbiji v članku obravnavamo najpogostejše načine tvorjenja besednih iger ter njihovo klasifikacijo glede na zgradbo. Vlogo besednih iger v oglaševanju razložimo z vidika teorije relevantnosti (Sperber in Wilson 1995) ter behaviorističnega modela AIDA. V članku tudi poskušamo ugotoviti, ali so v britanskih in srbskih bančnih ponudbah izkoriščeni formalni in semantični vidiki leksikalnih enot, kakor tudi obstoj jezikovnih in kulturnih značilnosti tvorjenja besednih iger.

Ključne besede: besedne igre; bančni oglasi; teorija relevantnosti; angleščina; srbščina 


\section{How to P(l)ay with Words? The Use of Puns in Online Bank Advertisements in English and Serbian in Light of Relevance Theory}

\section{Introduction}

Advertisements are very often characterised by the inventive use of language and unorthodox semantic functions of words. Figures of speech, also known as tropes and rhetorical figures, are widely employed, especially, as Leech $(1966,183)$ points out, because of their striking and memorable quality. Dyer $(1982,152)$ states that the purpose of figurative language is to create effects, attract attention and arouse emotions by breaking or exploiting rules. In this way, she argues, emotive associations are linked to the product.

A pun as a rhetorical figure plays an important role within the persuasion process, since it cleverly disguises certain messages in advertisements. McGuire (2000) emphasises the persuasion effect of using figurative language in communications and claims that rhetorical figures are often used: (a) to enhance attention to an advertisement; (b) to increase its believability along with the amount of information a consumer remembers; (c) to influence a consumer's mood; and finally, (d) to persuade them to purchase products or services. Sternkopf $(2005,227)$ adds that advertising language is highly ambiguous, since clear and concrete statements are avoided and vague utterances are used to activate numerous layers of potential interpretation.

This paper aims to explain the frequent puns ${ }^{1}$ employed in bank advertisements and to highlight their structure. It is interesting to observe how language is used in financial advertising, since people are generally cautious about the claims and tempting messages in bank offers. The idea is to explore whether puns are similarly used in two languages, and whether there are any culturespecific features attached to their use.

\section{Theoretical Framework}

The function of puns in advertising is explained and analysed in this paper from the perspective of Sperber and Wilson's relevance theory (1995), an inferential approach to pragmatics, later slightly modified and updated (Wilson and Sperber 2004), and the behavioural AIDA model, both of which are explained in the following sections.

\subsection{Relevance Theory}

Building upon Grice's cooperative principle and violation of maxims (1989), Wilson and Sperber centre their argument around the claim that the expectations of relevance raised by an utterance are precise and predictable enough to help the hearer infer the speaker's meaning $(2004,607)$. According to relevance theory, the search for relevance is a basic feature of human cognition. Hence, any input (e.g. an utterance) is regarded as relevant "when its processing in a context of available assumptions yields a positive cognitive effect" (Wilson and Sperber 2004, 608). It is argued that the more positive cognitive effects an utterance produces and the less processing effort it requires, the more relevant that utterance will be.

In this paper both terms - puns and wordplays - will be used interchangeably as synonyms to indicate the same deliberate semantic exploitation of words and phrases. 
The concept of ostensive-inferential communication is crucial in this theory. There are two intentions in communication:

a. the informative intention (the intention to inform the hearer of something) and

b. the communicative intention (the intention to have one's informative intention recognised)

Once the speaker's informative intention is recognised, the communicative intention is fulfilled and understanding is achieved. In other words, the hearer must first realise that the speaker has the intention to communicate something. The process of this communication actually involves the use of an ostensive stimulus "designed to attract an audience's attention and focus it on the communicator's meaning" (Wilson and Sperber 2004, 611), which means that only relevant stimuli will be noticed. More precisely, this stimulus needs to be optimally relevant, i.e. to fulfil the following two conditions if communication is to be successful: (1) to be relevant enough to be worth the audience's processing effort; and (2) to be the most relevant and economical one for the audience to process and understand it easily. Otherwise, the utterance will be uninterpretable and the speaker's meaning unidentifiable.

Tanaka $(1994,26)$ points out that although an utterance may communicate many assumptions, not all of them are intended at the same time by the speaker, as some are purely accidental. Among the intended assumptions, some are communicated explicitly while others are implicit. According to Sperber and Wilson $(1995,182)$, explicatures are assumptions obtained by the development of the logical forms encoded by an utterance. On the other hand, implicatures include contextual assumptions (implicated premises) and contextual implications (implicated conclusions) derivable from the proposition expressed by the utterance (1995, 194-195). They underline the fact that comprehension process is not linear. Instead, "hypotheses about explicatures and implicatures are developed in parallel against a background of expectations which may be revised or elaborated as the utterance unfolds" (Wilson and Sperber 2004, 615). The hearer starts with the decoded linguistic meaning with the least processing effort, which must be then contextually enriched at the explicit level and complemented at the implicit level up until the resulting interpretation meets his expectation of relevance and the speaker's meaning is yielded (Wilson and Sperber 2004, 613). Along the way there may be ambiguities to resolve, ellipses to interpret, metaphors and ironies to interpret, etc.

In terms of online advertising, attracting attention seems to be rather a challenging task because online competition is so vast and seemingly unlimited. Users now have greater control over choosing sites and products they see online or even excluding the advertising content with the help of application software. Therefore, many advertisements can be unnoticed or completely ignored. In other words, if the ostensive stimulus produced by the addresser fails to catch the attention of the audience, no communication can take place. Alternatively, when a potential buyer or client pays attention to a given ostensive stimulus, they find it relevant and want to continue processing it.

Byrne (1992) uses relevance theory for the analysis of the text to illustrate the role of linguistic style in advertising, which is used as a tool for conveying meanings beyond the ones verbalised. Such analysis can thus help in disambiguation, examination of different contextual implications and some typical features of advertising text. Tanaka $(1994,64)$ thinks that relevance theory offers the best framework for the analysis of the role of puns in advertising and the question of processing effort. Puns, however, may present a problem for this approach, because extra processing effort is needed for their interpretation. In this case, puns can be analysed as cases 
of layering in communication. As Tanaka $(1992,96)$ argues, puns do achieve optimal relevance exactly because the ostensive stimulus is the most economical way for the advertiser to achieve many of the intended contextual effects. This means that the production of an utterance which is apparently uninterpretable at one level may be used as an ostensive stimulus at another (Sperber and Wilson 1987, 751). Without going through the whole process, the audience would ignore the advertising caption and the message would lose its strength.

To put it in simpler terms, puns are extensively used in advertising although they make the hearer invest additional processing effort which would influence relevance. Nonetheless, positive cognitive effects compensate for the extra processing efforts used to resolve the pun, and these outweigh potential disadvantages (Díaz-Pérez 2012, 29). However, if a pun requires too much processing effort, the effect may be counterproductive, as it can produce confusion or even scepticism towards the product.

From the perspective of relevance theory, puns in advertising can be analysed in terms of the interpretation process involved (based on Tanaka 1994, 62-82) ${ }^{2}$ in the following ways:

1. two meanings are activated; one interpretation is to be rejected since it makes no sense and gives place to the intended one - nonsense puns,

2. the rejected interpretation provides access to encyclopaedic knowledge, which is then used in processing the intended interpretation - context-based puns,

3. one interpretation is activated; however, the message insinuates some things otherwise indecent or inappropriate to be overtly expressed - insinuating puns,

4. two (or more) meanings are activated and both of them are actually communicated complex puns.

Tanaka $(1994,62)$ states that "the essence of the pun lies in its access to multiple interpretations". Puns are successful if the hearer activates more than one interpretation of a given utterance no matter whether one interpretation is intended to be rejected or not. If two meanings are to be recovered and communicated, they have to reinforce one another.

Whatever linguistic or extralinguistic devices are used, the advertiser's main intentions are always the same - attracting and maintaining the audience's attention, making them remember the advertisement, associating the product with desirable qualities and persuading them to buy it. This is directly related to the AIDA model discussed in the next section.

\subsection{AIDA Model}

In order to properly understand the reasons for employing wordplay in advertising, we also need to emphasise a cognitive marketing concept crucial for the main aspects and functions of advertising communication, i.e. the behavioural AIDA model developed by Elmo Lewis (Strong 1925). This acronym stands for (attracting) Attention, (raising) Interest, (establishing) Desire and (initiating) Action, describing the sequential mental processes that may occur when the consumer sees an advert. It is used as a basic framework to explain how an advertising message is created, how it works and what linguistic means are used to make it effective. Different functions are realised with the use of language forms and images, i.e. different means can be used for

The boundaries between these types of pun are not clearcut, but rather a matter of degree (Tanaka 1994, 65). The ultimate message is reached when more than one interpretation is combined. 
a specific function (e.g. the use of trigger words, the choice of syntactic forms, direct reader addressing, metaphors, puns, etc.).

According to Kotler and Armstrong (2012, 417-18), the AIDA model suggests the desirable qualities of a good and effective message, which should, ideally, get attention, hold interest, arouse desire, and obtain action. However, not many messages actually take the consumer through all four steps, from awareness to purchase; instead, the model presents a solid theoretical starting point for establishing advertising objectives. They, further, emphasise that marketing communicators must decide what to say (the message content) and how to say it (the message structure and format).

Regarding the message content, the communicator first identifies an appeal that will produce a desired response and motivate purchase. There are three types of appeals:

(a) rational appeals,

which relate to the audience's self-interest and show the product's benefits;

(b) emotional appeals,

which provoke either positive (love, joy, humour) or negative emotions (fear, guilt);

(c) moral appeals,

which are directed to an audience's sense of what is right or wrong.

Regarding the structure and format, communicators have a range of different options to use. Structurally, they can, for example, draw conclusions for the product or let buyers make their own inferences by asking questions; they can present the strongest arguments first or last; or they can mention only the product's strengths or also admit its shortcomings. Formally, they can attract attention by using novelty, eye-catching pictures and headlines, distinctive colours, size or position, and so on.

Finally, Horky (2009) suggests how the AIDA model can be used in internet marketing, which is shown in Diagram 1. He notices that business objectives can be reached by combining the characteristics of traditional and internet marketing with elements of effective marketing communication models.

As can be seen from the diagram, there are numerous ways to realise the AIDA steps. However, it is quite rare to find an advert with a one-to-one relationship with the various steps proposed by the concept, since two or more steps normally merge together (Vestergaard and Schrøder 1985, 50). Consequently, the functions of language partially overlap and coincide, so a clear demarcation is not always possible.

The use of puns, as will be shown throughout the paper, is an effective way to realise all these steps, and thus they are frequently applied in commercial advertising. Puns surprise and provoke readers, as they have to decipher deeper meanings and solve a puzzle, after which they become interested in the product and they are more likely to eventually buy it. The product is hence promoted by "creating humour, attracting the reader's attention and adding persuasive force to the message" (Laviosa 2005, 25). With a puzzle to solve, the reader's attention is captured and the ultimate message, be it rather simple and obvious, is much more appealing. 


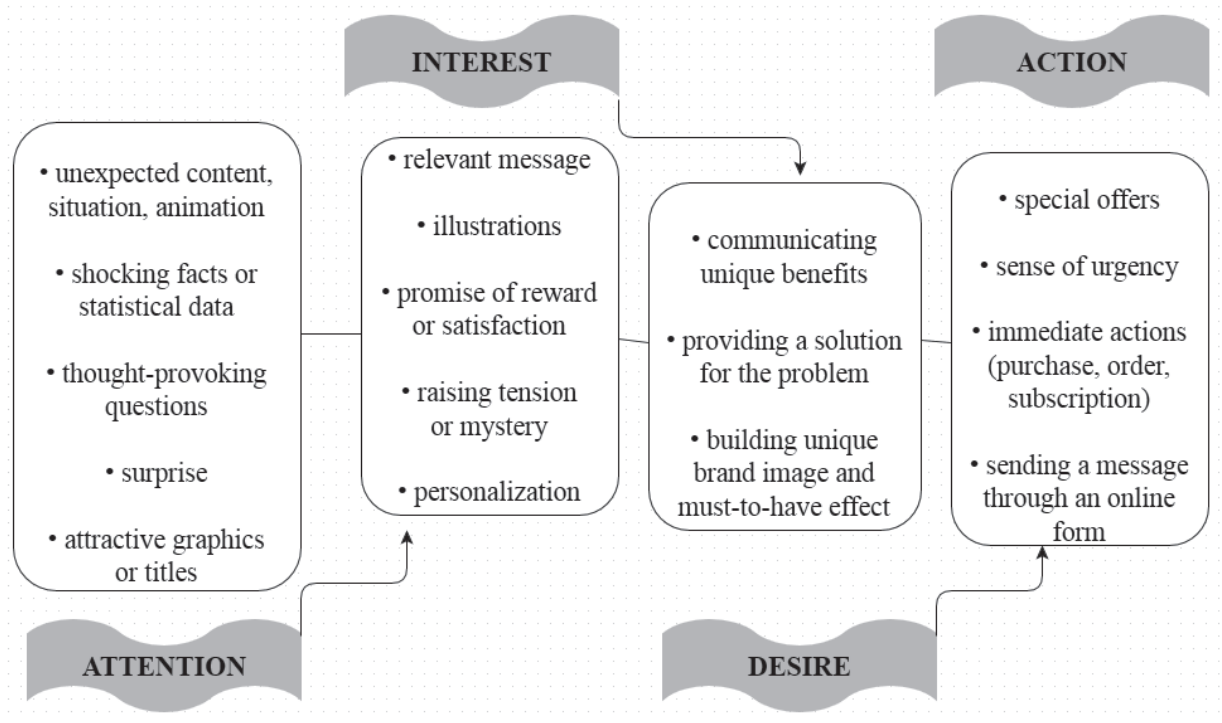

DiAgRAM I. AIDA model in internet marketing.

\section{Puns in Advertising}

Puns refer to "the use of words or phrases to exploit ambiguities and innuendoes in their meaning, usually for humorous effect" (Collins Cobuild online dictionary). More precisely, as Delabastita (1996, 128) explains, puns contrast "linguistic structures with different meanings on the basis of their formal similarity", which can be complete - homonymy, or partial - homophony, homography and paronymy. The context itself is vital, since it allows for multiple readings to be triggered and the pun to be activated and realised. Otherwise, these instances are regarded as unintentional wordplay. As Partington $(2009,1799)$ explains, "it is the interplay, the enforced switching from one mode of interpretation to another [...] which is at the heart of a great part of wordplay."

Crystal $(2003,405)$ points out that the two unrelated meanings of a single word are suddenly and unexpectedly brought together, and the consequent incongruity makes us laugh. Apart from their humorous effect, wordplay also captures and holds the attention of the audience (for different functions of wordplay, cf. Thaler 2016, 51-52). This is a very useful attentiongetting device based on intended ambiguity and alternative interpretations, which arise from the confrontation of similar forms but different meanings. According to Leech (1966, 184), ambiguity can be defined as a many-to-one relationship between levels, where:

a) different meanings are expressed by using the same word - polysemy, as in one British bank offer:

Sort your overdraft

where the verb to sort triggers two possible meanings - 'to arrange' and 'to deal with'; or

b) different meanings are expressed by words with the same phonological or graphological form - homonymy, as in one Serbian bank offer: 


\section{Nije u redu da čekate u redu. Predite na e-banking!}

[It is not all right to wait in a queue. Switch to e-banking! $]^{3}$

where the Serbian phrase $u$ redu is repeated in two different senses, as a phrase - 'to be all right / ok' and as a preposition + noun - 'in a queue'.

Even though they are thought to be inappropriate for serious discourse, due to their humorous nature and intention, puns are a perfect choice for advertising (Sherzer 1985). Redfern (1984, 131) thinks that the utility of puns in this context lies in the fact that they are highly economical in terms of advertising space, otherwise rather costly.

Although both advertising agencies and some influential copywriters in the 1960s and 70s (e.g. Ogilvy 1964; Caples 1974) were reluctant to admit that using a pun is extremely productive and effective, many research studies that followed proved that puns are popular rhetorical figures in advertisements. For instance, Leech (1966) lists the inventive and imaginative use of language as an important linguistic device available to copywriters when creating advertising material; Redfern (1984) thoroughly analyses puns using examples from advertisements and literature; Cook (1992) discusses the impact of puns in perfume and car advertisements; Tanaka (1994) observes that punning is an essential device in advertising; Myers (1994) speculates that puns appeal to readers because more work and time is required to process them and explains some popular examples; Leigh (1994) finds an abundance of puns in print ad headlines; both McQuarrie and Mick (1996) and Tom and Eves (1999) highlight the importance of language games and ambiguity. In an experimental setting, van Mulken, van Enschot-van Dijk, and Hoeken (2005) show that the presence or absence of puns has a significant impact on the respondents' appreciation of the related slogans. They state that puns give the audience both a pleasurable experience and intellectual satisfaction after solving a semantic riddle, which in turn may lead to a more positive attitude towards the product (van Mulken, van Enschot-van Dijk, and Hoeken 2005, 708). Furthermore, Djafarova (2008) explores the interpretation processes of puns in print advertisements of tour operators and discusses intended meanings in relation to the background and inferential knowledge of the audience. Labrador et al. (2014) focus on the rhetorical structure and the linguistic features of persuasive language in online advertisements of electronic products. They also identify puns and regard them as instances of language play indicating informal style. In a marketing-oriented research study, Choi, Taylor, and Lee (2017) investigate whether advertisements with puns are more effective and if they influence consumers' attitude toward the brand.

Although numerous research studies have been conducted with the aim of revealing semantic peculiarities in commercial advertising, very few have addressed and investigated the matter in a specific advertising sector - financial products and services (cf. Albers-Miller and Straughan 2000; Adams and Cruz García 2007; Lazović 2014). Trust in banks has declined in recent years due to the significant, negative impact the global financial crisis has had on ordinary people's lives. Moreover, as a result of severe competition, banks are constantly trying to restore and retain trust by offering safety, security and reliability in the post-crisis period. For that reason, advertisements for financial products have their own unique features compared to other types of advertisements, such as the abundance of restrictions, the key role of numbers, factual and objective tone, infrequent use of neologisms, etc. (Adams and Cruz García 2007). Bank advertisements present banks as trustworthy and reliable, while emphasising their stability and security. They often play

All the examples in Serbian are translated into English by the author. 
on audiences' aspirations, which, as they promise, are easily affordable and accessible. They are regarded as more serious compared to advertisements for cosmetic products, food and drink products, etc. However, they also share some typical or universal characteristics, such as short, dense texts, usually with the abundance of ellipsis, in the form of slogans, clichés and telegraphic descriptions of a product emphasising its advantages (Lazović 2014).

In light of relevance theory, advertisements use a range of devices to attract the attention of potential buyers. These devices frustrate the expectation of relevance they have created, because the audience will try to discover the hidden meaning. The ultimate message is usually obvious, although disguised so as to be more appealing and challenging to decipher. Puns, for example, create extra positive cognitive effects, and in such a way increase the relevance of both the advertisement and the message(s) conveyed. The message is in this way communicated with more strength. While solving the puzzle the audience's attention is retained longer, and thus once the pun is comprehended it is often remembered (Tanaka 1994, 71). Increased memorability is thus a major advantage derived from more processing effort. The longer the pun takes to process, the more likely the audience will memorise it. On the other hand, if there is no pun and the message is straightforward, this considerably lowers the chances of the audience remembering advertisements and possibly reacting to them.

Surprisingly enough, the advertiser is not concerned with a positive impact of the pun. Even if some people find a pun obscure or irritating, this will still be welcomed by the advertiser, since they consider that in terms of product recognition evoking any kind of reaction, either positive or negative, is better than evoking no reaction.

\section{Research Questions and Research Methodology}

This research study investigates puns in advertisements found in the UK and Serbian bank offers online. The analysis of online bank advertisements is conducted in order to reveal the structure of puns exploited in the two languages. Several research questions are addressed:

1. Are puns a common technique in the UK and Serbian bank advertisements?

2. Is the structure of puns the same in the two languages?

3. Does the usage vary between languages and is this variation culturally-bound?

4. What are possible interpretations of puns in light of relevance theory?

This comparative analysis features a particular type of advertisements, namely bank advertisements, because advertisements for financial services are thought to be among the most boring and predictable of those from any sector (Myers 1999, 38). Jewler $(1992,49)$ notes the problems copywriters face when they have to write a caption for a bank account and struggle to think of yet another way of saying that "our interest rates on long-term certificates of deposit aren't the worst in town". In addition, it is a highly competitive category, with new banks constantly emerging. It is thus very challenging for banks to compete, because in the public's mind there is not much that differentiates one institution from another (Jewler 1992, 49). Finally, bank advertisements are chosen in order to examine the claim proposed by Adams and Cruz García $(2007,143)$ that press adverts for financial products infrequently use puns, and to investigate whether this applies to online adverts as well.

The analysis of different puns in this paper is based on the self-compiled corpus. Online bank advertisements were continually followed and collected over the course of one year, i.e. from 
May 2012 to May 2013. The analysed corpus comprises 570 Serbian and 770 UK online bank advertisements offering services on the official home pages of the 32 most prominent banks operating in the UK and 33 banks operating in Serbia at the time of corpus collection. All the advertisements are planned, aimed and directed at consumers rather than corporations. In order to provide a consistent and uniform data sample of advertising text to be analysed, the following criteria were applied for advertisement selection:

1. An advertisement is found on the homepage of the commercial bank regardless of the position on the page and the size.

2. An advertisement either features bank's services or services of their partners.

3. An advertisement for financial products is directed at the general public rather than at experts.

4. An advertisement is either text-based (e.g. only slogans), graphic-based (e.g. only images) or most often, both text- and graphic-based.

5. Multimedia elements, such as audio and video sequences, are not included in the corpus.

6. The product or service advertised belongs to the retail personal banking sector, not private, business or corporate banking sector.

7. Only the text found in the advertisement is analysed, whilst detailed descriptions and explanations ${ }^{4}$ found on the transferred sites are excluded.

For this type of comparative analysis, the instances of puns are first identified and then classified according to their underlying structure. The representative examples are further interpreted within the advertising context following the principles of relevance theory to reveal hidden meanings. The study is qualitative and exploratory in nature. Since the discussion centres around the verbal component, visual puns are excluded from any further discussion.

\section{Findings}

This part focuses on different structures of puns, examples of which are illustrated and explained. The primary purpose of the present study is to build upon the prior research (Tanaka 1992, 1994; Byrne 1992; Díaz-Pérez 2000, 2012) and examine the use of puns in bank advertisements using the two frameworks previously introduced.

In order to make puns effective, different linguistic features are exploited along with different forms of knowledge about the world and culture. Thaler $(2016,52)$ observes that there is an almost unlimited range of possibilities to modify linguistic material creatively, which makes it difficult to offer any comprehensive list of wordplay structure (for one possible taxonomy of puns in English cf. Koren 2012).

Based on the recurrent types of wordplay in bank adverts and different language levels exploited, the classification offered here is a slightly modified and expanded version of the one found in Delabastita (1996, 130-31). The idea is to illustrate and describe the most common instances found in both corpora. Puns are therefore classified into six groups, five of which concern different linguistic structures, while the sixth heavily relies on extralinguistic knowledge. Nevertheless, it should be pointed out that the boundaries between these groups are not clear-cut, since different

The detailed overviews of services along with explanations and details on loan repayment, interest rates, additional benefits, terms, etc. do not constitute an advert anymore, and as such could be analysed separately. 
levels of language are often simultaneously activated for a single pun to be understood, e.g. graphological, morphological, lexical, syntactic, and textual.

\subsection{Graphological Structure}

Puns based on the bank name incorporated with other words were found only in the Serbian corpus, as illustrated in examples (1) and (2). The name of the bank is followed by the service, merging into the slogan or advertising phrase:

\section{(1) OTPakujte vaše račune \\ [Unpack your accounts] \\ (2) OTPlaćujte stan sa lakoćom! \\ [Repay your flat with ease!]}

The wordplay is based on grapho-morphological merging. Unlike English, Serbian has a simple and logical spelling system, where each of 30 letters in the alphabet corresponds to one sound. In Example 1, OTP, the name of the bank, is combined with the word pakovati [to pack], to produce the new word otpakujte [to unpack; imperative, 2nd person plural]. In the second one, the compound consists of the bank's name and the word plaćati [to pay] resulting in otplaćujte [to repay; imperative, 2nd person plural]. These new coinages indirectly imply that the bank easily enables those services. Generally speaking, coinages are created to give uniqueness, vigour and impact to the advertising message (Dyer 1982, 150). Using relevance theory and considering the fact that both advertisements promote bank services, the pun is used to provide additional positive cognitive effects and implicated contextual assumptions, which could be recovered as (i) and (ii):

i. Our bank is always there to help you with important decisions (account activation, repayment).

ii. These services are very simple and easy to get when compared to other banks.

In addition, the well-established acronym of the bank, PBB banka (Privredna $\underline{b} a n k a$ Beograd), is cleverly incorporated in the slogan in the following two examples:

(3) Planirajmo $\underline{B}$ olju $\underline{B} u d u c$ nost

[Let's Plan Better Future]

(4) Praktičnije $\underline{B}$ olje $\underline{B} r z ̌ e$

[More Practical Better Faster]

The acronyms trigger two interpretations, both of which perfectly fit the context. The bank helps you plan a better future and is more practical, better and faster in terms of services and costs compared to others. These implications also create a positive image of the bank.

Another bank advertises a credit card called Panter [Panther]. The caption goes as follows:

(5) Kupuj sigurrrno i nosi pantera sa sobom!

[Buy safely and carry a panther with you!]

The humorous reading is reinforced with the image of the person patting a real panther, as the card is both textually and visually presented as an animate entity. ${ }^{5}$ The caption further contains an onomatopoeic wordplay triggered by altered spelling, not reflected in the translation, since the word sigurrrno, features three r's, which imitate the sound of a panther angrily growling.

Along with puns, metaphors are very common in bank advertisements. However, they are not further addressed nor analysed in this paper. 
Wordplay based on graphological structure is rather scarce in the British advertisements analysed in this study. There is, though, one that promotes a special credit card and a special current account with the same name - as shown in examples (6) and (7):

(6) 123 CREDIT CARD

Get cashback on everyday spending

(7) 123 CURRENT ACCOUNT

Switch your current account with our

5-Star Rated Switcher Service

The numbers are directly associated with the benefits obtained if you choose these services. Literally, it means that you will get $1-3 \%$ cashback depending on where you use the credit card ( $1 \%$ at all major supermarkets, $2 \%$ at all major department stores and $3 \%$ at all major petrol stations). Also, you can earn 1-3\% cashback if you pay household bills using this current account. In these two examples the pun may not be immediately obvious, as the audience is satisfied with the first interpretation - the name of the service matches the amount of cashback. However, the effective combination of the benefits and the simile as easy as 123 enables another reading and expands the existing one. When this intended interpretation is recovered and processed, the following implicated contextual assumptions about the services are created:

iii. It is extremely easy and simple to activate this current account / this credit card.

iv. These services are both easy to get and use.

Yet again, the bank contributes to the creation of positive cognitive effects which reinforce a positive image of the advertised product and/or service. At the same time, the bank improves the chances of attracting more clients and promoting services in the best possible way.

\subsection{Morphological Structure}

As noted by Delabastita (1996, 130), in most morphological puns "words are construed as compounds or derivatives in a way which is etymologically 'incorrect' but semantically effective." No example was found to illustrate compounds which lost their original transparency, as in breakfast, for example. Instead, the puns in the corpora mostly rely on grapho-morphological structure and originate from the assumption that the given words are analysable units sharing the same root or affixes. The following advertising messages in (8) and (9) illustrate this type of pun:

(8) Sve(t) na dohvat ruke!

implying two possible meanings referring to the use of cards:

\section{Sve na dohvat ruke! [Everything at your fingertips!] \\ 2. Svet na dohvat ruke! [The world at your fingertips!]}

Although sharing the same letters, sve [everything] and svet [the world] are unanalysable units, which are not related. Cleverly disguised into the message aiming to promote a credit card, this pun calls for two interpretations with clear positive cognitive effects being: 
v. With our card you can buy everything all over the world.

vi. You can use the card anywhere.

vii. Our bank offers you everything.

Furthermore, the unrelated free morphemes fun and fund are brought together in (9):

\section{(9) Putting the fun into fundraising}

The advertiser emphasises this link while assigning new meanings. As a result, the audience may think of fundraising as an enjoyable and pleasant activity, and hence encouraged to collect and donate money.

In addition, new word combinations in bank offers are also produced by adding a letter to the existing word, as shown in examples (10) and (11):

(10) Bez brige. Kredit je (o)siguran.

implying two possible meanings:

1. Bez brige. Kredit je siguran. [No worries. The loan is safe.]

2. Bez brige. Kredit je osiguran. [No worries. The loan is insured.]

\section{(11) Proveri pa poveri}

implying two possible meanings referring to the savings - first, check

terms, offers and rates of other banks and then entrust your money:
1. Proveri
[Check]
2. Poveri
[Entrust]

Such grapho-morphological combinations additionally reinforce multiple readings and maintain multilayered communication between the advertiser and audience.

\subsection{Lexical ${ }^{6}$ Structure - Polysemy}

Myers $(1994,66)$ observes that wordplay based on polysemy is far more common in advertising than that based on homonymy. Puns based on different meanings of polysemic words are ubiquitous in the corpus. Moving from literal to figurative meaning back and forth, these words trigger multilayered communication and thus positive associations. The following example (12) in Serbian illustrates this:

\section{(12) Sve karte su u vašim rukama}

[All cards are in your hands]

The noun karte [cards] can refer literally to debit / credit cards the bank offers and the caption would then read: you hold all the cards in your hands. This interpretation would produce positive cognitive effects, such as (viii) and (ix), and maybe even (x):

$6 \quad$ The term lexical is used here in a broad sense, including both the forms and meanings of words. In terms of punning, lexical items are both carefully chosen and deliberately manipulated to trigger multilayered meanings. Although I am fully aware that the terminology is not the most appropriate for the analysed semantic phenomenon, I decided to follow the classification found in Delabastita (1996). I would like to thank the reviewer for their insightful comments on this point. 
viii. I can use the cards quickly and easily.

ix. The cards are always there when I need them.

x. This bank offers everything I need.

The whole phrase can convey a figurative meaning 'to have control over your decisions', further implying something along the lines of (xi) and (xii):

xi. You have full control over your finances if you use our cards.

xii. Our bank helps you decide what is best for you.

The full potential of the pun is reached when both literal and figurative interpretations are simultaneously activated.

Moreover, there is an interesting advert for an energy efficiency loan, as shown in example (13):

(13) Bezpromaje - i u stanu i u novčaniku

[No draught ${ }^{7}-$ neither in your flat nor in your wallet]

The first part of the sequence is interpreted in its literal sense, because a draught occurs when doors and windows are not properly sealed. Reducing air leakage in your home prevents excessive energy loss, but also reduces bills and minimises costs. The 'saving money' interpretation is activated with the second part, which is rather challenging for translation, since the idiomatic phrase promaja $u$ novčaniku in Serbian means 'the wallet is empty', i.e. a person is penniless, but to the British a draught in your wallet does not evoke the same association and as such would be confusing. Therefore, the implication is that your wallet will not be empty and you will save money.

The same process takes place in British bank offers, which is illustrated and explained in examples (14) and (15):

(14) New mortgage? Good move.

See if we can find you a mortgage that will save you money

In this example, the polysemous nature of the noun move enables several messages to be communicated. Let us start with the more obvious ones, as in (xiii) and (xiv):

xiii. Taking out a new mortgage at our bank is a good decision.

xiv. The process of changing homes will be smooth and will not cause any problems.

Both interpretations evoke positive associations and neither of them is rejected. Rather they complement each other since both are equally relevant for the audience. Furthermore, there is a possibility that this pun can also activate some deeper meanings, as suggested in (xv) and (xvi):

xv. A new mortgage will improve your way of living.

xvi. You will progress with a new mortgage.

The myth surrounding a draught is a socio-cultural phenomenon in Serbia since people tend to believe that it causes various problems (health problems included). 
The phrase good move can also be connected with playing chess, hence it could be further speculated that the advertiser wanted to activate the concept of winning, since good moves increase the chances of winning both in sports and life.

Another example of polysemous words and phrases in the British offers is shown in (15):

(15) Your account at your fingertips

With our app or by text message

The caption includes the phrase at your fingertips, which can be understood literally - using your fingertips to type necessary information and click on the mobile app in order to access your account. When advertising mobile banking services, the intended meaning is more probably figurative - to have all the information about your account readily available and easily accessible.

Given the above-mentioned examples, it may be wrongly assumed that a pun almost always communicates two (or more) meanings. In the next example, one interpretation is rejected as irrelevant:

\section{Sainsbury's Nectar Credit Card Sweet shopping}

The pun in example (16) centres around the adjective sweet, which in combination with the noun shopping triggers the figurative meaning to describe the activity which makes you feel happy and satisfied. The literal meaning of sweet is triggered in relation to the card's name Nectar, only to be rejected as irrelevant.

\subsection{Lexical Structure - Fractured Phraseological Units}

Another very common technique found in the analysed corpora is a play on phraseological elements, i.e. the use of well-known phrases, where fixed word combinations are altered in order to generate certain meanings by different modifications. Beasley and Danesi $(2002,123)$ claim that the clever use of phraseology both imparts a sense of proverbial qualities to the product and generates a high connotative index. Myers $(1994,73)$ also mentions fractured collocations, where one word is deliberately replaced or a collocation is used in a new context, thus evoking specialised meanings and settings. Examples found in the corpus illustrate the modifications of fixed phraseological units, which are either:

a) associated with financial products, and hence given new interpretations:

(17) Ima leka za dobro le enje.

Finansijska podrška za medicinske ustanove.

[There is a cure for good treatment.

Financial support for medical institutions]

(18) 1 za sve

Sakupite sve svoje dugove u 1 kredit i pla ajte manje!

[1 for all

Collect all your debts into 1 loan and pay less!] 
In the Serbian examples (17) and (18), the well-known idiom ima leka [there is a cure] refers to the bank's financial support, which can help medical institutions provide good treatment, while the part of the musketeers' motto one for all' is unexpectedly linked to one loan and all the debts which are to be paid back. Similarly, in the English example (19), the well-known saying all's not lost suggests that the situation can be improved, in this case when the card is lost. The informal ${ }^{8}$ phraseological unit say no more in (20) implies that all the hidden meanings are understood and no more details are needed. Referring to additional fees, the following interpretation can also be derived - you will no more have to pay card usage fees.

b) slightly reworded within the bank advertising message:

(21) Sve vam je popušteno \%

[Everything is discounted \% for you]

(22) Od duplog glava ne boli!

[Double never hurts!]

(23) Bank your way with HSBC

The past participle in example (21) within the phraseological units sve vam je oprošteno [you are forgiven everything] or sve vam je dopušteno [you are allowed everything] is changed to popušteno [discounted] and reinforced by the percentage sign, with the effect of attracting clients on the basis of a discount. In addition, example (22) in Serbian is a modified version of the idiom od viška glava ne boli [a little extra never hurts] applied to the interest rate for savings, which is doubled as part of the bank's special offer. In their advertisement shown in example (23), the British bank changes the collocation make your way into bank your way, suggesting that you will progress if you use their services.

\subsection{Syntactic Structure}

Syntactic ambiguity occurs when phrases or sentences can be parsed in more than one way, and it relies on the syntagmatic links between lexemes. For instance, the advertisement for a child's savings account reads as follows:

\section{Stednja za decu Blago deci! \\ [Savings for children \\ Treasure to children! / Lucky children!]}

On a surface level, the purpose of the caption in example (24) is twofold: (a) to promote savings and (b) to encourage parents to open such an account. However, by analysing its syntactic structure further, new interpretations appear. The slogan blago deci can be analysed as a noun (nominative case) + noun (dative case) combination. The noun blago [treasure] can refer to money, gold, jewellery

$8 \quad$ Informal words and phrases are otherwise very rare in the register of bank advertising (Adams and Cruz García 2007). 
or any accumulated wealth, but also figuratively, to prosperity and well-being. On the other hand, this combination can be analysed as an interjection + noun (dative case), which is used to express satisfaction, happiness and joy. Although it can also be used ironically to show envy and jealousy, this interpretation is rejected here. With a recovery of syntactic relations, the pun provides access to contextual assumptions, which contribute to several positive cognitive effects, among others:

xvii. By saving in our bank you will accumulate money for your children.

xviii. Your children are lucky because you save for them.

xix. Your children will have treasure.

xx. Your children will be prosperous.

In example (25), the advertiser plays with the word bank. The message is also visually divided in two lines:

(25) Bank with the best...

\section{Best Current Account Provider}

After reading the first line, the audience is very likely to process it as a noun + prepositional phrase, where dots create an anticipation effect. The idea is to make the reader fill in the gap with a service or a product the bank offers (e.g. Bank with the best interest rates / terms and conditions etc.). In other words, the reader wonders about the reasons why this bank is the best. Moving to the second line, there is a clear shift into a verb + prepositional phrase. The first interpretation is immediately rejected.

\subsection{Shared Knowledge of Culture and Current Events}

Finally, there is wordplay based on extralinguistic knowledge, where some influence of cultural elements and current affairs can be recognised. In Serbia, for example, politics is one of the most popular topics for discussion, so banks get their message across by reflecting and referring to political affairs, which are interwoven with everyday life, as in example (26):

(26) Koalicija dobrih uslova

[A coalition of good terms]

This was the advertising message for a savings account during a post-election period, when the coalition agreement between two political parties was expected. Hence, the word koalicija [coalition] can refer both to the government formation of the two parties or literally, to the synthesis of good terms the bank offers.

In addition, the services are offered in connection with current events, as is the case with the beginning of the academic year for students in October. One advert for the bank account, specifically designed for students and their needs, contains the message:

(27) Pravo je vreme za desetku

[It's the right time for ten $]^{9}$

where desetka [ten] refers both to the highest student's mark and to the name of the student's account.

In Serbia, the grading system at the tertiary level depends on the number of points obtained during the course and at the exam, ranging from 5 (insufficient) to 10 (excellent - exceptional). 
In example (28), the advertisement draws upon popular cultural knowledge and stereotyping:

(28) How do you like your bank account?

Because everyone's different, we offer a broad range of current account to suit every taste.

The bank offers different current accounts by asking potential clients How do you like your bank account? along with the image of a teapot. Another interpretation is triggered only when a verbal message is interpreted along with the visual. The visual component is crucial here, since it evokes a habit of drinking tea and suggests the alternative readings, such as How do you like your tea?, making a parallel with the kind of current account that would suit the client's taste. Therefore, a common British ritual is used to advertise the bank service. This causes the audience to use extra processing effort if they are to recover the alternative interpretation.

It should be noted, though, that the puns in (26)-(28) rely on shared knowledge between the advertiser and the audience in terms of cultural values, lifestyles and current events. Double interpretation is activated if and only if such knowledge exists. Otherwise, the pun would be unsuccessful and the intended message unclear to the audience.

\section{Conclusion}

The analysis presented in this paper revealed how the two languages are creatively used and how semantic rules are frequently broken in advertising. It was once again demonstrated that advertisements extensively use wordplay to maximise contextual implications and create a positive image of the focal product, regardless of language and culture. Tanaka $(1994,82)$ thinks that these language devices attract and retain attention, while Beasley and Danesi $(2002,102)$ claim that if the advert's textuality is ambiguous, it is more likely to create greater interest and generate appeal. As a consequence, this may affect the audiences' attitudes to the advert, and ultimately, the advertised product.

With regard to the research questions, this research study clearly demonstrated that puns are very useful attention-getting devices and that playing with linguistic and extralinguistic material is an effective advertising technique in both the British and Serbian bank offers. Both languages exploit the potential of punning even in more serious contexts, i.e. online bank advertisements, which is in contrast with the results for press advertisements for financial products reported by Adams and Cruz García (2007). Formal and semantic aspects of lexical units are creatively used on different levels. Interestingly enough, Serbian proved to be equally productive in terms of punning when compared to English, unlike some other languages (for a comparison between English and Spanish cf. Díaz-Pérez 2012). The findings also showed that the Serbian advertisements exploited graphological potential more than the British offers. The most frequent puns found in both corpora were complex ones with at least two interpretations being simultaneously activated. Sometimes, though, shared knowledge between the advertiser and the audience is crucial for deciphering and understanding a pun. In addition, some of the examples presented in this study show that puns do not necessarily fulfil a humorous function, but primarily capture and hold the attention of the audience, which is in line with the AIDA model.

This paper also demonstrated how relevance theory can be used to explain puns as ostensive stimuli in advertising discourse. Since they produce additional contextual effects, puns serve an important function in bank advertising and largely contribute to the overall and intended 
interpretations and effectiveness of the message. These additional positive effects justify all the extra processing effort demanded from the audience to recover the intended message. As a result, puns are likely to be remembered, and so can further create a positive attitude towards the focal product or service.

Finally, the examples in this paper were discussed in terms of their verbal component. Nonetheless, since images are equally important message carriers, future research could address visual puns and examine how these can reinforce or change intended meanings triggered by the accompanying verbal text, and how they function as ostensive stimuli. The image used can narrow down the possible choices of word meanings, encourage particular readings and help solve double interpretations. Therefore, it would be of great interest to examine the changes in meaning prompted by the accompanying visuals.

\section{References}

Adams, Heather, and Laura Cruz García. 2007. "The Advertising of Financial Products in the Press." Ibérica 13: 123-46.

Albers-Miller, Nancy D., and Robert D. Straughan. 2000. "Financial Services Advertising in Eight NonEnglish Speaking Countries.” International Journal of Bank Marketing 18 (7): 347-58. https://doi. org/10.1108/02652320010359561.

Beasley, Ron, and Marcel Danesi. 2002. Persuasive Signs: The Semiotics of Advertising. Berlin: Mouton de Gruyter.

Byrne, Barbara. 1992. Relevance Theory and the Language of Advertising. Dublin: Trinity College Dublin.

Caples, John. 1974. Tested Advertising Methods. Fourth Edition. Englewood Cliffs, NJ: Prentice-Hall.

Choi, Jieun, Charles R. Taylor, and Doo-Hee Lee. 2017. "Do Resonant Advertisements Resonate with Consumers?” Journal of Advertising Research 57 (1): 82-93. https://doi.org/10.2501/JAR-2017-007.

Collins Cobuild Online Dictionary, https:/www.collinsdictionary.com/

Cook, Guy. 1992. The Discourse of Advertising. London: Routledge.

Crystal, David. 2003. The Cambridge Encyclopedia of the English Language. Second Edition. Cambridge: Cambridge University Press.

Delabastita, Dirk. 1996. “Introduction.” The Translator 2 (2): 127-39. https://doi.org/10.1080/13556509.19 96.10798970.

Díaz-Pérez, Francisco Javier. 2000. “Sperber and Wilson’s Relevance Theory and its Applicability to Advertising Discourse. Evidence from British Press Advertisements”. Atlantis 22 (2): 37-50.

—. 2012. "The Use of Wordplay in Advertisements Published in Men's Magazines. A Comparative Study in the UK and Spain." Estudios Ingleses de la Universidad Complutense 20: 11-36. https://doi.org/10.5209/ rev_EIUC.2012.v20.39993.

Djafarova, Elmira. 2008. "Why do Advertisers Use Puns? A Linguistic Perspective." Journal of Advertising Research 48 (2): 267-75. https://doi.org/10.2501/S0021849908080306.

Dyer, Gillian. 1982. Advertising as Communication. London: Routledge.

Grice, H. Paul. 1989. Studies in the Way of Words. Cambridge, Massachusetts: Harvard University Press.

Horky, Vit. 2009. “Guerrilla Marketing Online.” Accessed April 22, 2013. http://www.guerrillaonline.com/cs/ Guerrilla-Marketing-Principles-54.htm 
Jewler, A. Jerome. 1992. Creative Strategy in Advertising. Fourth Edition. Belmont, California: Wadswort.

Koren, Ana. 2012. "An Honest Attempt to Grasp and Possibly Tame the Wild Animal of Punning Taxonomy." ELOPE 9 (2): 23-37. https://doi.org/10.4312/elope.9.2.23-37.

Kotler, Philip, and Gary Armstrong. 2012. Principles of Marketing. 14th Edition. Boston: Pearson Prentice Hall.

Labrador, Belen, Noelia Ramón, Hector Alaiz-Moretón, and Hugo Sanjurjo-González. 2014. "Rhetorical Structure and Persuasive Language in the Subgenre of Online Advertisements." English for Specific Purposes 34: 38-47. https://doi.org/10.1016/j.esp.2013.10.002.

Laviosa, Sara. 2005. "Wordplay in Advertising: Form, Meaning and Function.” Scripta Manent 1 (1): 25-34.

Lazović, Vesna. 2014. "The Language of Online Bank Advertisements in English.” ESP Today 2 (1): 88-104.

Leech, Geoffrey. 1966. English in Advertising: a Linguistic Study of Advertising in Great Britain. London: Longman.

Leigh, James H. 1994. "The Use of Figures of Speech in Print Ad Headlines.” Journal of Advertising 23 (2): $17-33$.

McGuire, William J. 2000. "Standing on the Shoulders of Ancients: Consumer Research, Persuasion, and Figurative Language.” Journal of Consumer Research 27 (1): 109-14. https://doi.org/10.1086/314312.

McQuarrie, Edward F., and David G. Mick. 1996. "Figures of Rhetoric in Advertising Language." Journal of Consumer Research 22 (4): 424-38. https://doi.org/10.1086/209459.

Myers, Greg. 1994. Words in Ads. London: Arnold.

—. 1999. Ad Worlds: Brands, Media, Audiences. London: Arnold.

Ogilvy, David. 1964. Confessions of an Advertising Man. New York: Atheneum.

Partington, Alan S. 2009. "A Linguistic Account of Wordplay: The Lexical Grammar of Punning." Journal of Pragmatics 41 (9): 1794-809. https://doi.org/10.1016/j.pragma.2008.09.025.

Redfern, Walter. 1984. Puns. Oxford: Blackwell.

Sherzer, Joel. 1985. "Puns and Jokes." In Handbook of Discourse Analysis, vol. 3: Discourse and Dialogue, edited by Teun A. van Dijk, 213-21. London: Academic Press.

Sperber, Dan, and Deidre Wilson. 1987. “Authors' Response." Behavioral and Brain Sciences 10 (4): 736-54.

—. 1995. Relevance: Communication and Cognition. Second Edition. Oxford: Blackwell Publishers.

Sternkopf, Sylva-Michele. 2005. English in Marketing: International Communication Strategies in Small and Medium-Sized Enterprises. Berlin: Frank \& Timme.

Strong, Edward K. 1925. The Psychology of Selling and Advertising. New York: McGraw-Hill.

Tanaka, Keiko. 1992. “The Pun in Advertising: A Pragmatic Approach.” Lingua 87 (1-2): 91-102. https:// doi.org/10.1016/0024-3841(92)90027-G.

—. 1994. Advertising Language: A Pragmatic Approach to Advertisements in Britain and Japan. London: Routledge.

Thaler, Verena. 2016. "Varieties of Wordplay." In Crossing Languages to Play with Words. Multidisciplinary Perspectives, edited by Sebastian Knospe, Alexander Onysko and Maik Goth, 47-62. Berlin, Boston: De Gruyter. https://www.degruyter.com/view/product/468240

Tom, Gail, and Annmarie Eves. 1999. "The Use of Rhetorical Devices in Advertising." Journal of Advertising Research 39 (4): 39-43.

van Mulken, Margot, Renske van Enschot-van Dijk, and Hans Hoeken. 2005. "Puns, Relevance and 
Appreciation in Advertisements." Journal of Pragmatics 37 (5): 707-21. https://doi.org/10.1016/j. pragma.2004.09.008.

Vestergaard, Torben, and Kim Schrøder. 1985. The Language of Advertising. Oxford: Basil Blackwell.

Wilson, Deidre, and Dan Sperber. 2004. "Relevance Theory." In The Handbook of Pragmatics, edited by Laurence R. Horn and Gregory Ward, 607-32. Oxford: Blackwell. 